\title{
THE REMOVAL OF INDIGO CARMINE FROM WATER BY SOLVENT SUBLATION
}

\author{
T. Obushenko, N. Tolstopalova, Y. Kholmetska \\ National Technical University of Ukraine «Igor Sikorsky Polytechnic Institute» \\ e-mail: $\underline{\text { tio63@mail.ru }}$
}

In this research, which includes the previously published works of this team on dyes removal, solvent sublation was applied in order to remove such dyestuff as Indigo carmine from model solutions. The aim of the work was to study the main principles of Indigo carmine removal from water by solvent sublation. Indigo carmine (IC, $\mathrm{C}_{16} \mathrm{H}_{8} \mathrm{~N}_{2} \mathrm{Na}_{2} \mathrm{O}_{8} \mathrm{~S}_{2}$ ), an anionic dye, was removed from aqueous solutions by solvent sublation of an IC-hexadecylpyridinium bromide $(H P B)$ complex (sublate) into octanol. The effects of the following parameters on solvent sublation were experimentally studied: the molar ratio of HPB:IC, $p H$ of aqueous phase, duration of the removal process, type and volume of organic solvent. The initial dye concentration was $10 \mathrm{mg} / \mathrm{dm}^{3}$.

It was found that the process should be conducted under such conditions: $p H 5$, solvent octanol, Schott filter nominal pore size - $16 \mu \mathrm{m}$, molar ratio of HPB:IC $=1: 1$, process duration$20 \mathrm{~min}$. According to obtained results the highest level of IC elimination that was reached within the experiment equals 95,5\%.

Keywords: dye, indigo carmine, hexadecylpyridinium bromide, solvent sublation, spectrophotometry.

\section{Introduction}

It's well-known that water is a unique substance which disappearence will cause the death of every living organism. Despite the key role of water in the human life these days the deterioration of nature water quality is increasing rapidly. Annually around $450 \mathrm{~m}^{3}$ of effluent, which contains wide range of pollutants is discharged directly into the rivers and other surface water basins. More than a half of this amount doesn't undergo any effective pretreatment. Unfortunately, Ukraine doesn't remain beyond this ecological problem, moreover, it endures its exacerbation phase. According to international standards, mainly all of our big rivers and their tributaries, belong to the category of polluted or highly polluted waters. There are numerous rivers where the content of one or several impurities exceeds the maximum allowable concentration (the M.A.C.) in dozens of times, for example, the Dnipro, the Desna, the Styj River, the Siverskyj Donets and others. The accumulation of toxic effluent components is a considerable hazard to water resources potential of the country. It particularly relates to waste water pollutants, which belong to II-IV hazard classes such as organic dyes and diluents. The main sources of water pollution by dyes are the following: textile industry, chemical plants, cellulose and paper industry and pharmaceutical industry. It is assumed that during dye production the loss of target product is nearly 1-2\% and for reactive dyes, this value can be about 4\% [1]. Perhaps, this is caused by dye dilution in the water used for its synthesis and the amount of such water is enormous: it takes approximately $100-225$ tons of water to produce 1 ton of dye [2]. Textile industry also stands out, as it yields a large amount of effluents. It is estimated that about $10-15 \%$ of dyes are released into processing water during different procedures [3]. So it's obvious that the discharge of such raw effluent into the surface water entails highlevel pollution thus in natural water dyes concentrations highly exceed affordable limits $(0.05-$ 
$0.25 \mathrm{mg} / \mathrm{dm}^{3}$ ). Due to complicated chemical structure of synthetic dyes they can't be biochemically decomposed in aqueous systems therefore local treatment plants are not able to cope with this problem. Synthetic dyes are also extremely hazardous pollutants of natural environment due to the effect of potentiation. Consequently, such interactions are often unexpected. Entering the environment dyes easily colour the water and surrounings consequently cause unfavorable aesthetic impression, deteriorating organoleptic properties of water. In addition, dyes can significantly affect the photosynthesis ability of the water inhabitants by decreasing water transparency. Dyestuff can be toxic for some flora and fauna species because of aromatic rings and chlorine substituents in their structure [3]. This can lead to total extinction of water living organisms, self-treatment processes disruption and human intoxication. Hence synthetic dyes can cause significant environmental pollution and bring a serious risk factor for human diseases too. There are different methods of wastewater treatment that provide either elimination or destruction of dyes such as: chemical processes (the use of Fentons reagent, ozonation, photocatalytic decolourization, electrochemical destruction), physical treatments (adsorption, membrane filtration, ion exchange, electrokinetic coagulation, etc.) and microbiological decomposition [4]. However all these techniques are often too expensive for applying, ineffective or produce much sludge. Therefore the search for more effective, inexpensive and low-waste method for dyes remediation from water still remains actual. In this case, solvent sublation is a good alternative. In this special adsorptive bubble separation non-foaming technique some organic solvent is placed on the top of aqueous phase and is used to collect the sublate adsorbed on the bubble surfaces of an ascending gas stream. This method with its advantages of simultaneous separation and concentration has recently attracted much attention in many fields. Based on the previous reports and recent researches the following advantageous of solvent sublation can be outlined: 1) high separation efficiency; 2) high concentration coefficient; 3) low dosage of organic solvent; 4) soft separation process; 5) simple operation and equipment [5]. Moreover, this technique provides the possibility of the further dye recovery after its elimination [6-13]. The removal of IC, an anionic dye from aqueous solution by solvent sublation was studied. IC can cause some environmental problems, the search of a simple and effective removal method is necessary. In this work the efficiencies of solvent sublation with some conventional separation methods were compared.

\section{Materials and methods}

The solvent sublation process took place in glass column. It was $50 \mathrm{~cm}$ in length with an initial diameter of 3,5 cm and had 2 access ports. The gas bubbles were generated in a Schott filter with porosity of $16 \mu \mathrm{m}$. Compressed nitrogen was supplied by the gas cylinder and moved through the humidifier and the filter to the bottom of the solvent sublation column. Gas rate was measured by flow meter. To obtain dye concentration in the aqueous phase, the sample solution was withdrawn from the top access port for analysis. Reagent-grade HPB was used as a collector without further purification. Reagent grade IC and the other reagents were all analytical grade. For the solvent sublation running, HPB was added to the sample solution $\left(250 \mathrm{~cm}^{3}\right)$ to form the dyesurfactant complex; the solution contained $10 \mathrm{mg} / \mathrm{dm}^{3}$ IC and was poured into the sublation column; $5 \mathrm{~cm}^{3}$ of octanol was added immediately; then the timer was started and the samples of aqueous solution were taken for analysis at specified times. The $\mathrm{pH}$ of the solution was measured with a pH-meter Portlab 102. UV-visible spectra of the sample solutions were measured with a scanning spectrophotometer Portlab 501.

\section{Results and discussion}

Parameters, which affect the solvent sublation process can be classified as those, that affect the aqueous and organic solutions and those, which are operational factors. Parameters of the first 
group are: aqueous phase composition ( $\mathrm{pH}$, ionic strength, presence of various species), organic phase composition (organic solvent: type and volume). The operational parameters are: gas flow rate, temperature, process duration. $\mathrm{PH}$ of the aqueous solution is a very important factor because it determines the presence of ionic species, which are involved in solvent sublation process. Such processes as hydrolysis, complex formation and precipitation of insoluble substances are governed by $\mathrm{pH}$ values of aqueous solutions. The presence of surfactant is also very important factor for solvent sublation because usually it makes extracted ion-pairs more hydrophobic. In addition, surfactants tend to reduce the surface tension of aqueous solution and decrease the size of bubbles generated in the sparger [6]. Hexadecyl-pyridium-bromide was used as the surfactant in all cases because it showed high efficiency in the process of IC removal by solvent sublation during previous researches. It's known, the higher sublate solubility in organic layer is the, bigger efficiency of dye removal is obtained. In this research different organic compounds were investigated to find out the proper one. The next compounds were used as the organic solvent: hexan, heptan, butyl acetat, butanol, pentanol and octanol (Fig.1).

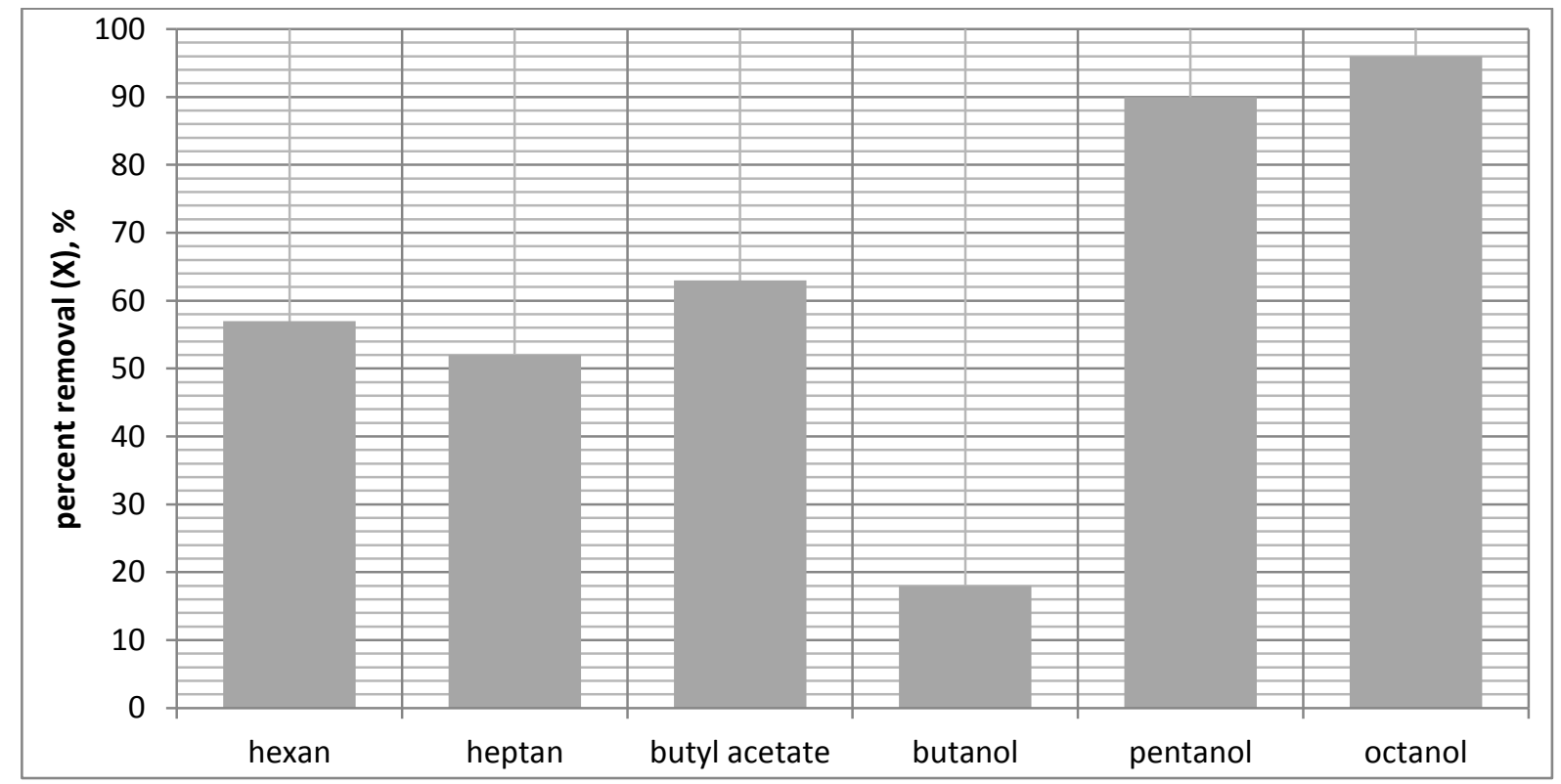

Fig. 1. The variation of IC removal efficiency in dependence of the organic solvent type. HPB:IC (mole ratio) $1: 1, \mathrm{pH} 5$, pore diameter $16 \mu \mathrm{m}$.

In the solvent sublation system, octanol was chosen as the organic solvent, which has a high solubility of the IC- HPB, immiscible to the aqueous phase, low-aqueous-organic solvent interfacial tension, nontoxic, and nonvolatile.

Therefore in this study the experiment was conducted under the maximum permitted gas flow rate condition $\left(40 \mathrm{sm}^{3} / \mathrm{h}\right)$. At higher gas flow rates, the oil-water interface can be drastically disrupted and some drops of the top organic layer can return back to solution.

\section{The effect of process duration on solvent sublation}

Dye concentration in the aqueous phase was measured every 5 minute for 30 minutes. As graph shows (Fig. 2) the optimum process duration was equal to 20 minutes with $95 \%$ IC removal accordingly. 


\section{The effect of the molar ratio of HPB to IC}

A series of experiments were carried out using solutions at $\mathrm{pH}$ with different HPB to IC molar ratios while keeping the airflow rate at $40 \mathrm{~cm}^{3} / \mathrm{min}$. The effect of concentration HPB on the solvent sublation of IC is shown in Fig.3. It was found that the efficiency of separation improved with the increase of molar ratio of surfactant to IC, and that the efficiency became highest at 1:1. At a smaller concentration of the surfactant, the rate of removal was slower and the level of the residual dye greater, presumably due to incomplete formation of a dye-surfactant complex.

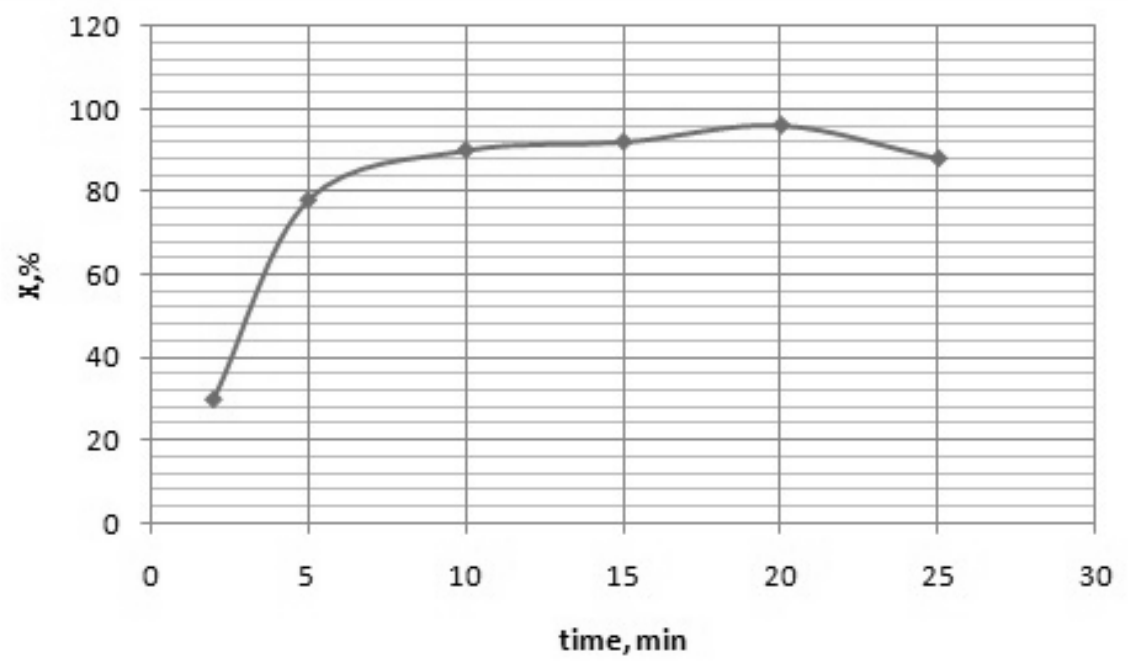

Fig. 2. The variation of IC removal efficiency in dependence of the elapsed time. HPB:IC (mole ratio) $=1: 1$.

However, when the ratio was greater than $1: 1$, the rate of solvent sublation was smaller and the removal efficiency was slower, presumably due to the competition for the bubble surface by the excess surfactant ion with the dye-surfactant complex. It was observed that the excess surfactant could also cause the emulsification of the octanol (which was observed during the solvent sublation process with a larger excess of surfactant), and the dye-surfactant complex in the octanol was constantly dispersed back into the solution to decrease the separation significantly.

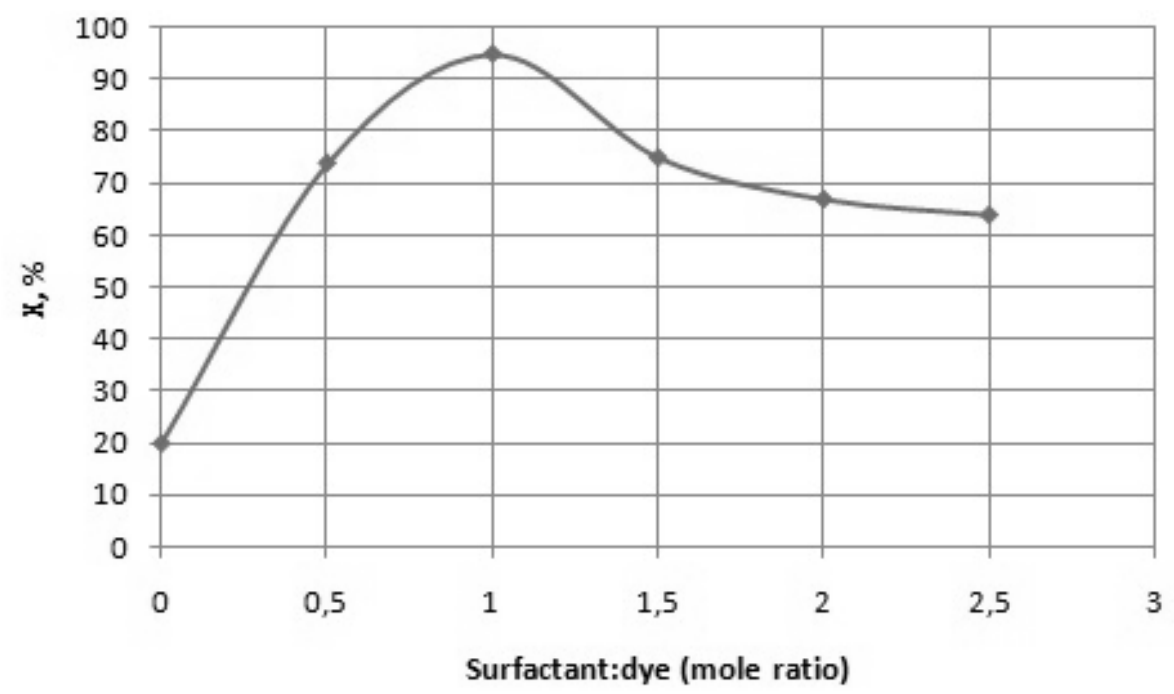

Fig. 3. The dependence of IC removal efficiency on the molar ratio of HPB to IC. 
Within this research the influence of such organic frame particularities as carbon chain length and the degree of branching in the carbon chain was investigated.

The effect of $\mathrm{pH}$ on solvent sublation

The effect of $\mathrm{pH}$ on the removal of IC - HPB in the process of solvent sublation is shown in Fig. 4. The removal rate and removal efficiency of IC increased with the increase of the value of $\mathrm{pH}$, and reached the most high removal efficiency at the natural $\mathrm{pH}$ value, then decreased with the increase of the $\mathrm{pH}$ value. At the natural $\mathrm{pH}$ value over $90 \%$ of IC was removed from the solution by solvent sublation in $5 \mathrm{~min}$. But at lower $\mathrm{pH}$ value, the removal rate and efficiency decreased.

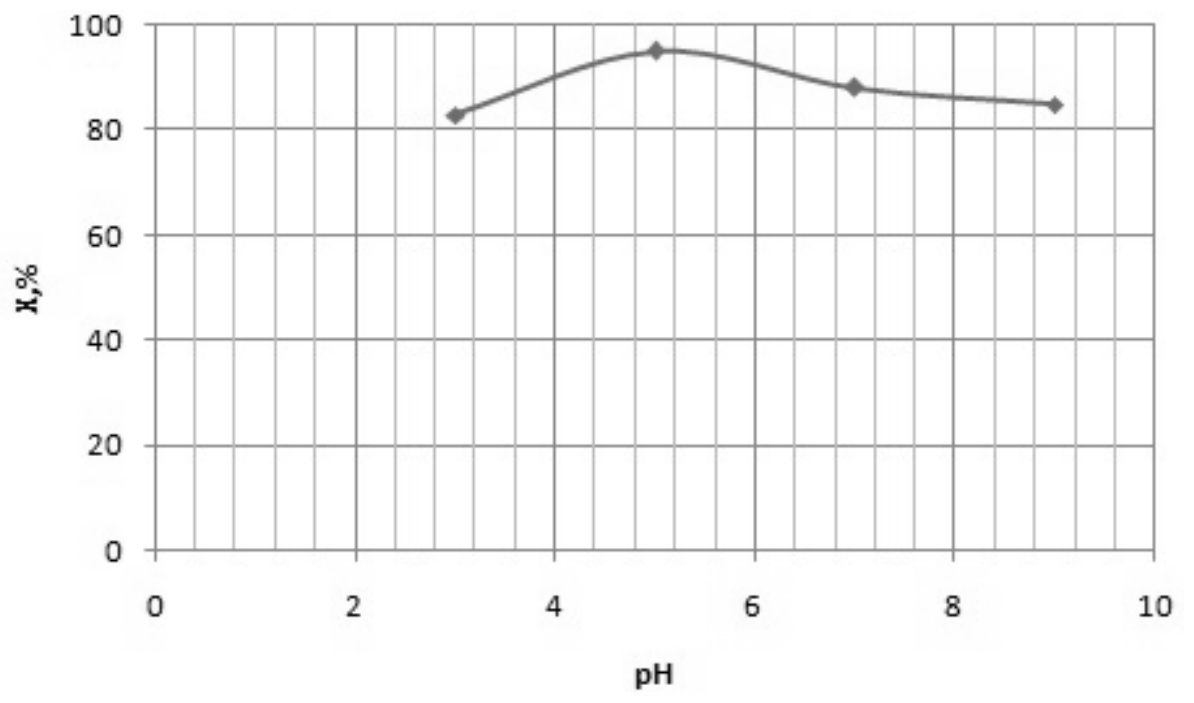

Fig. 4. Effect of $\mathrm{pH}$ on solvent sublation. $\mathrm{C}$ (IC) $=10 \mathrm{mg} / \mathrm{dm}^{3}$, ratio $\mathrm{HPB}$ of to $\mathrm{IC}=1: 1, \mathrm{Vw}$ $250 \mathrm{~cm}^{3}$, rate of air flow $40 \mathrm{~cm}^{3} / \mathrm{min}$, duration of air flow $20 \mathrm{~min}$.

The Effect of the Volume Ratio of Organic Solvent to Aqueous for Solvent Sublation

It is known that in the case of the solvent sublation of ion-surfactant complexes from aqueous solution into octanol, the removal efficiency is independent from the amount of the octanol volume [6]. We achieved the same result with these experiments, which are shown in Fig. 5. No significant improvement in removal efficiency was observed, when the volume of octanol exceeded $5 \mathrm{~cm}^{3}$ in the $250 \mathrm{~cm}^{3}$ solution. The results showed that sublation was independent from the volume of organic solvent until the saturation of phase occurs by the sublate. Generally, mass-transfer occurs from gas bubbles crossing the aqueous-solvent interface and not from diffusion of solute across this interface, the amount of material transferred should depend only on the amount of air crossing the interface and not on the organic volume.

While in liquid-liquid extraction the volume ratio of the two immiscible phases is a very important parameter, which is an important difference between the liquid-liquid extraction and solvent sublation. But if the organic volume used in solvent sublation is too low, the extragentwater interface will be drastically disrupted at a high air flow rate and the process will lose its efficiency. Hence the air flow rates and solvent volume must be chosen to keep the minimal disruption of the interface. 


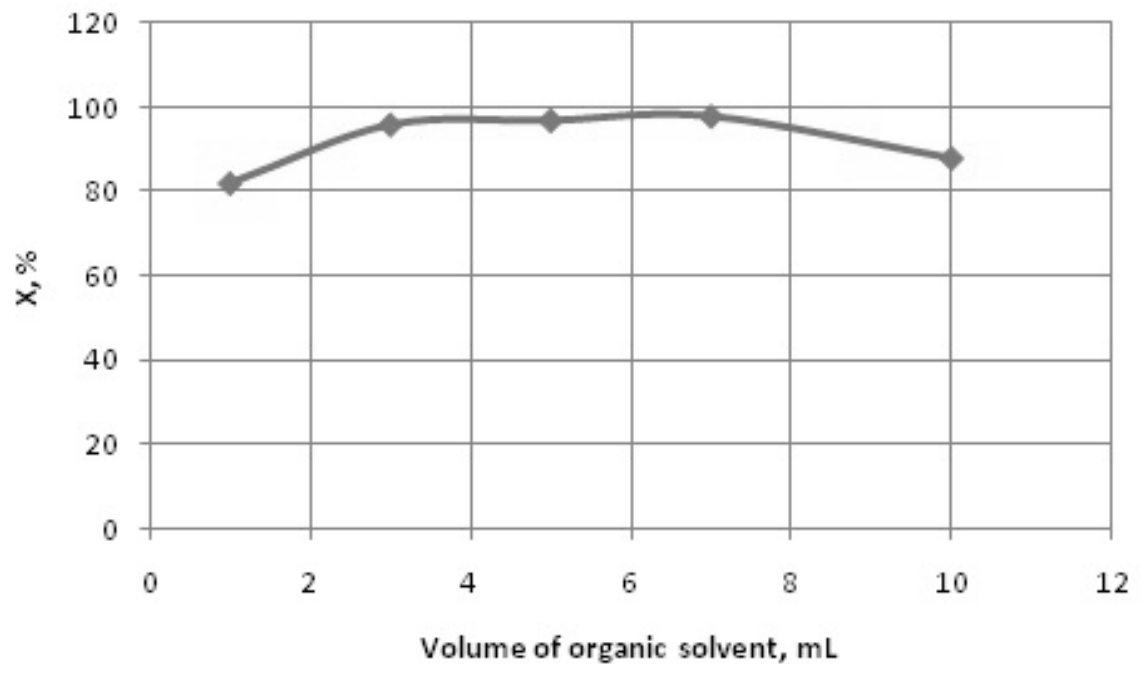

Fig. 5 Effect of solvent volume on solvent sublation, C (IC) $=10 \mathrm{mg} / \mathrm{dm}^{3}$, ratio of HPB to IC $=1: 1$, rate of air flow $40 \mathrm{~cm}^{3} / \mathrm{min}$.

\section{Conclusions}

To sum up, within this report contemporary state of water pollution problem, caused by synthetic dyes was analysed, covering the main methods that are typically used for dyes decomposition and remediation. Solvent sublation was proposed as an effective alternative. The main principles of Indigo carmine removal from water by solvent sublation were investigated. The following major parameters and their influence on Indigo carmine removal from water were researched in detail: type and volume of organic solvent, the molar ratio of surfactant to dye, $\mathrm{pH}$. The highest dye removal was obtained in the case of octanol used as the solvent. The initial dye concentration was $10 \mathrm{mg} / \mathrm{dm}^{3}$.

It was found that the process should be conducted under such conditions: the natural $\mathrm{pH}$, solvent - octanol, Schott filter nominal pore size $-16 \mu \mathrm{m}$, molar ratio surfactant:dye $-1: 1$, process duration $-20 \mathrm{~min}$. The recovery efficiency was $95,5 \%$. Attained results can be used in further studies.

\section{УДАЛЕНИЕ ИНДИГО КАРМИНА ИЗ ВОДЫ ФЛОТОЭКТРАКЦИЕЙ}

\section{Т.И. Обушенко, Н.М. Толстопалова, Ю.М. Холмецкая}

Национальный технический университет Украины «Киевский политехнический институт имени Игоря Сикорского»

e-mail: tio63@mail.ru

Представленье результаты являются логическим продолжением исследований по флотоэкстракционному извлечению красителей на примере модельных растворов индиго кармина (ИК). Целью данной работы было изучение основных закономерностей удаления ИК флотоэкстракцией. Индиго кармин (ИК, $\left.\mathrm{C}_{16} \mathrm{H}_{8} \mathrm{~N}_{2} \mathrm{Na}_{2} \mathrm{O}_{8} \mathrm{~S}_{2}\right)$, анионньій краситель, извлекался из водного раствора флотоэкстракцией ИК-гексадецилпиридиния бромид (ГПБ) комплекса (сублат) в октанол. Экспериментально было исследовано влияние на флотоэкстракцию следуюших параметров: мольное соотношение ГПБ:ИК, рН водной фазы, длительность 
прочесса извлечения, природа и объем органического растворителя. Исходная концентрация

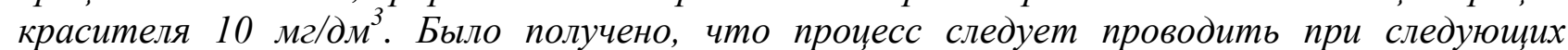
условиях: pH 5, экстрагент - октанол, размер пор фильтра Шотта 16 мкм, молярное соотношение ГПБ :ИК=1:1, продолжительность процесса 20 мин. Согласно полученным результатам, самая высокая степень извлечения ИК в эксперименте равна 95,5\%.

Ключевые слова: краситель, индиго кармин, гексадецилпиридиний бромид, флотоэкстракция, спектрофотометрия.

\title{
ВИЛУЧЕННЯ ІНДИГО КАРМИНУ 3 ВОДИ ФЛОТОЕКТРАКЦИЕЮ
}

\section{Т.І. Обушенко, Н.М. Толстопалова, Ю.М. Холмецька}

\author{
Національний технічний університет України «Київський політехнічний Інститут \\ імені Ігоря Сікорського» \\ e-mail: $\underline{\text { tio63@mail.ru }}$
}

\begin{abstract}
Результати, щзо представлено, $\epsilon$ логічним продовженням досліджень 3 флотоекстракиійного вилучення барвників на прикладі модельних разчинів індиго карміну (IK). Метою представленої роботи було вивчення основних закономірностей видалення IK флотоекстракиією. Індиго кармін (IK, $\mathrm{C}_{16} \mathrm{H}_{8} \mathrm{~N}_{2} \mathrm{Na}_{2} \mathrm{O}_{8} \mathrm{~S}_{2}$ ), аніонний барвник, вилучали 3 водного розчину флотоекстракцією IK - гексадецилпіридинію бромид (ГПБ) комплексу (сублат) в октанол. Експериментально було досліджено вплив на флотоекстракцію наступних параметрів: мольне співвідношення ГПБ:ІК, рН водної фази, тривалість процесу вілучення, природа та об'єм органічного розчинника. Вихідна концентрація барвника 10 мг/дм. Було отримано, щзо процес слід проводити при наступних умовах: рН 5, екстрагент - октанол, розмір пор фільтру Шотта 16 мкм, молярне співвідношення ГПБ:ІК = 1:1, тривалість процесу 20 хвил. Згідно отриманим результатам, найбільш высока ступінь вилучення IК в експерименті складає 95,5\%.
\end{abstract}

Ключеві слова: барвник, індиго кармін, гексадецилпіридиній бромід, флотоекстракція, спектрофотометрія.

\section{References}

1. Forgacs E., Cserha T., Oros G. Removal of synthetic dyes from wastewaters: a review. Environment International, 2004, 30, pp. $953-971$.

2. Nesterova L., Saribekov H. The efficiency of the use of circulating water consumption systems in textile plants. South-European Journal of Advanced Technologies, 2010, 4/8 (46), pp. 25-28.

3. Singh L., Singh V.P. Biodegradation of Textile Dyes, Bromophenol Blue and Congored by Fungus Aspergillus Flavus. Environ. We Int. J. Sci. Tech., 2010, 5, pp. 235- 242.

4. Robinson T., McMullan G., Marchant R., Nigam P. Remediation of dyes in textile effluent: a critical review on current treatment technologies with a proposed alternative. Bioresource Technology, 2001, 77, pp. 247-255.

5. Bi P., Dong H., Dong J. The recent progress of solvent sublation. Review. Journal of Chromatography A, 2117 (2010), pp. $2716-2725$.

6. Sobianowska K., Walkowiak W., Kozłowski C. Principles and application of solvent sublation - a Review. Ars Separatoria Acta, 7(2009/2010), pp.23 - 38. 
7. Lu Y. Wang Y., Zhu X. The Removal of Bromphenol blue from Water by Solvent Sublation. Separation Science and Technology, 2001, 36 (16), pp.3763 - 3776.

8. Astrelin I. M., Obushenko T. I., Tolstopalova N. M., Targonska O. O. Teoretichni zasadi ta praktichne zastosuvannja flotoekstrakciyi: ogljad. Water and water purification technologies, 2013, no. 3, pp. 3-23.

9. Obushenko T., Tolstopalova N., Kulesha O., Astrelin I. Remediation of anionic dye (Bromphenol blue) from aqueous solutions by solvent sublation. "Science news" KPI ", Issue Problems of Chemistry and Chemical Technology, 2015, no. 2, pp.125-133.

10. Obushenko T.I., Tolstopalova N.M., Bolielyi A.S. Solvent sublation of methylene blue from water. European science, 2017, no. 4 (26), pp.10-13.

11. Obushenko T.I., Astrelin I.M., Tolstopalova N.M., Batjuk V.O. Solvent sublation of dyes from wasterwater. Eastern-European Journal of Enterprise Technologies, 2012, no. $\quad 2 / 14$ (56), pp. 68-72.

12. Obushenko T.I., Tolstopalova N.M., Astrelin I.M. Removing Synthetic dyes from wastewater. Science Rise, 2016, Vol.5, no. 2 (22), pp. 47-53.

13. Obushenko T., Tolstopalova N., Kulesha O., Astrelin I. Thermodynamic studies bromphenol blue removal from water using solvent sublation. Chemistry \& chemical technology, 2016, Vol. 10, no. 4, pp.515-518. 